\title{
PEMBERDAYAAN KEMANDIRIAN EKONOMI MELALUI PRODUK INTELEKTUAL KAMPUS POLIBATAM PRESS DI POLITEKNIK NEGERI BATAM
}

\section{ECONOMIC EMPOWERMENT THROUGH INTELLECTUAL PRODUCT POLIBATAM PRESS IN POLITEKNIK NEGERI BATAM}

\author{
Nanik Lestari $^{{ }^{*} \text {, Mega Mayasari }}{ }^{2}$, Metta Santiputri ${ }^{3}$, Uuf Brajawidagda ${ }^{4}$ \\ 1,2(Prodi Akuntansi, Jurusan Manajemen Bisnis, Politeknik Negeri Batam, Indonesia) \\ ${ }^{34}$ (Prodi Multimedia dan Jaringan, Jurusan Teknik Informatika, Politeknik Negeri Batam, Indonesia) \\ 1ㅁnanik@polibatam.ac.id ${ }^{1)}{ }^{2}$ mega@polibatam.ac.id ${ }^{2},{ }^{3}$ metta@polibatam.ac.id ${ }^{3)},{ }^{4}$ uuf@polibatam.ac.id ${ }^{4)}$
}

\begin{abstract}
Tahun 2000 perguruan tinggi di Batam mulai tumbuh. Sejak itu juga berbagai gagasan dan karya ilmiah dihasilkan oleh berbagai perguruan tinggi di Batam. Penyebarluasan gagasan dan karya ilmiah tersebut membutuhkan dukungan penerbit buku yang handal. Polibatam Press adalah entitas Politeknik Negeri Batam di bidang penerbitan. Berbagai strategi digunakan untuk memajukan Polibatam Press antara lain perekrutan sumber daya manusia dari mahasiswa aktif, penyusunan Standar Operasional Prosedur (SOP) untuk pelayanan konsumen, produksi dan quality control, dan sebagainya. Pada tahun 2019, Polibatam Press telah menghasilkan 10 (sepuluh) buku ber-ISBN dan berbagai produk lain seperti seminar kit. Dengan adanya Polibatam Press ini, juga diperoleh tambahan pendapatan dan tersediaan bahan ajar dan modul praktikum untuk Politeknik Negeri Batam.
\end{abstract}

Kata-kata kunci: penerbitan, Polibatam Press, SOP, buku ber-ISBN

\begin{abstract}
In 2000 higher educations in Batam has start growing. Since then, ideas and academic writings have been produced by those higher education institutions. The dissemination of ideas and academic writings require a reliable publishing entity. Polibatam Press is one of Politeknik Negeri Batam's entity in publishing. Different strategies have been implemented to succeed Polibatam Press, such as human resource recruitment from active students of Politeknik Negeri Batam, establish the Standard Operational Procedures (SOP) for production and quality control, etc. In 2019, Polibatam Press has published 10 (ten) books with ISBN and other diverse product,example souvernir. Therefore, with Polibatam Press installment, Politeknik Negeri Batam has received additional revenue, texsbooks and practicum module.
\end{abstract}

Keywords: publisher, Polibatam Press, SOP, books with ISBN

\section{PENDAHULUAN}

Penerbit atau penerbitan merupakan suatu industri yang berkonsentrasi memproduksi dan memperbanyak sebuah literatur dan informasi atau sebuah aktivitas membuat informasi yang dapat dinikmati publik. Penerbit dari sistem penerbitannya dapat dibedakan sebagai penerbitan umum (konvensional) dan juga penerbitan mandiri atau self-publish, dimana penulis sebagai penerbitnya. Secara tradisional, istilah ini mengacu kepada usaha 
pendistribusian dari usaha percetakan seperti buku dan surat kabar. Perkembangan sistem teknologi informasi, istilah penerbitan mengalami perluasan makna, di mana memasukkan unsur-unsur buku elektronik, seperti dalam sebuah situs web atau pun blog (Wikipedia, 2019).

Buku-buku yang diterbitkan di Indonesia saat ini harus memiliki ISBN atau International Serial Book Number. ISBN adalah nomor pengidentifikasi unik pada setiap buku yang dikeluarkan oleh Perpusnas RI. Perpusnas RI merupakan lembaga yang ditunjuk untuk mengeluarkan ISBN di Indonesia, ISBN diperlukan sebagai identitas terhadap suatu judul buku, sebagai tanda hak cipta atas kepemilikan buku agar buku tidak disalahgunakan, serta mempermudah arus pendistribusian buku (Deepublisher, 2019).

Di Indonesia sendiri para penerbit buku dihimpun dalam sebuah asosiasi profesi penerbit. Salah satu sosiasi yang menghimpun para penerbit tersebut adalah Ikatan Penerbit Indonesia (IKAPI) yang didirikan pada tanggal 17 Mei 1950 di Jakarta. Pada tahun 2018 jumlah penerbit yang tercatat menjadi anggota IKAPI ada 1488 anggota penerbit dari seluruh Indonesia (IKAPI, 2019).

Batam memiliki potensi yang sangat baik untuk mendirikan sebuah penerbit buku. Berdasarkan data perkembangan jumlah perguruan tinggi (PTN maupun PTS) tiap provinsi tahun 2017/2018 PDDIKTI di Kepulauan Riau terdapat 33 perguruan tinggi swasta maupun negeri (PDDIKTI, 2018), sedangkan jumlah penerbit yang ada di Batam dan terdaftar di keanggotan IKAPI hanya ada 5 penerbit (IKAPI, 2019). Sehingga potensi pendirian usaha penerbitan buku sangat besar.

\section{METODOLOGI}

Politeknik Negeri Batam merupakan pendidikan vokasi yang mempunyai empat jurusan yaitu Manajemen Bisnis, Teknik Elektronika, Teknik Informatika, dan Teknik Mesin. Jurusan Manajemen Bisnis memilki tiga program studi yaitu Akuntansi, Akuntanis Manajerial dan Administrasi Bisnis. Salah satu ciri khas pendidikan vokasi adalah komposisi kurikulumnya menyebutkan bahwa praktikum (laboratorium) lebih besar dibandingkan dengan teori. Selain itu lulusan dari pendidikan vokasi harus mempunyai standar kompetensi yang tertuang dalam kurikulum yang berstandar SKKNI. Dalam rangka mengimplementasikan kurikulum berbasis SKKNI dan komposisi praktikum yang lebih besar 
tersebut maka diperlukan modul guna memberikan pemahaman yang komprehensif kepada mahasiswa.

Berdasarkan permasalahan diatas kami tim pengabdian mengusulkan Progam Pengembangan Usaha Produk Intelektual Kampus (PPUPIK) yang berupa yang berupa Politabam Press: Penerbitan Buku Ajar dan Modul Praktikum dalam rangka menuju kemandirian dan jiwa wirausaha Politeknik Negeri Batam. Konsep yang kami kembangkan berupa Digital Printing. Keunggulan cetak digital printing yaitu dapat memproduksi dengan harga yang lebih ekonomis, proses produksi cepat dengan kualitas yang lebih baik dan ramah lingkungan serta tidak ada batasan minimal pemesanan. Jenis usaha Polibatam Press termasuk jenis usaha jasa (pelayanan) yaitu menjaga kualitas pelayanan melalui penerapan standar pelayanan prima kepada konsumen serta menerapkan control quality sebelum produk diserakan kepada konsumen. Jasa pelayanan yang diberikan oleh Polibatam Press berupa penerbitan buku maupun jasa percetakan.

Pada tahun 2017, Politeknik Negeri Batam membentuk Polibatam Press sebagai sarana civitas akademika untuk mengatualisasikan diri baik dalam karya buku ajar atau modul praktikum. Sejak pendirian sampai tahun 2018, Polibatam Press sudah menghasilkan sebanyak tiga buah buku ajar ber- ISBN. Tiga buku tersebut adalah buku ajar Multimedia: Media Pembelajaran Untuk Menghasilkan Karya Multimedia, buku ajar Pengolahan Citra Digital dan buku ajar Rangkaian Listik, dimana para penulisnya merupakan dosen pengajar di Politeknik Negeri Batam. Berikut ini adalah gambar produk yang dihasilkan oleh Polibatam Press:

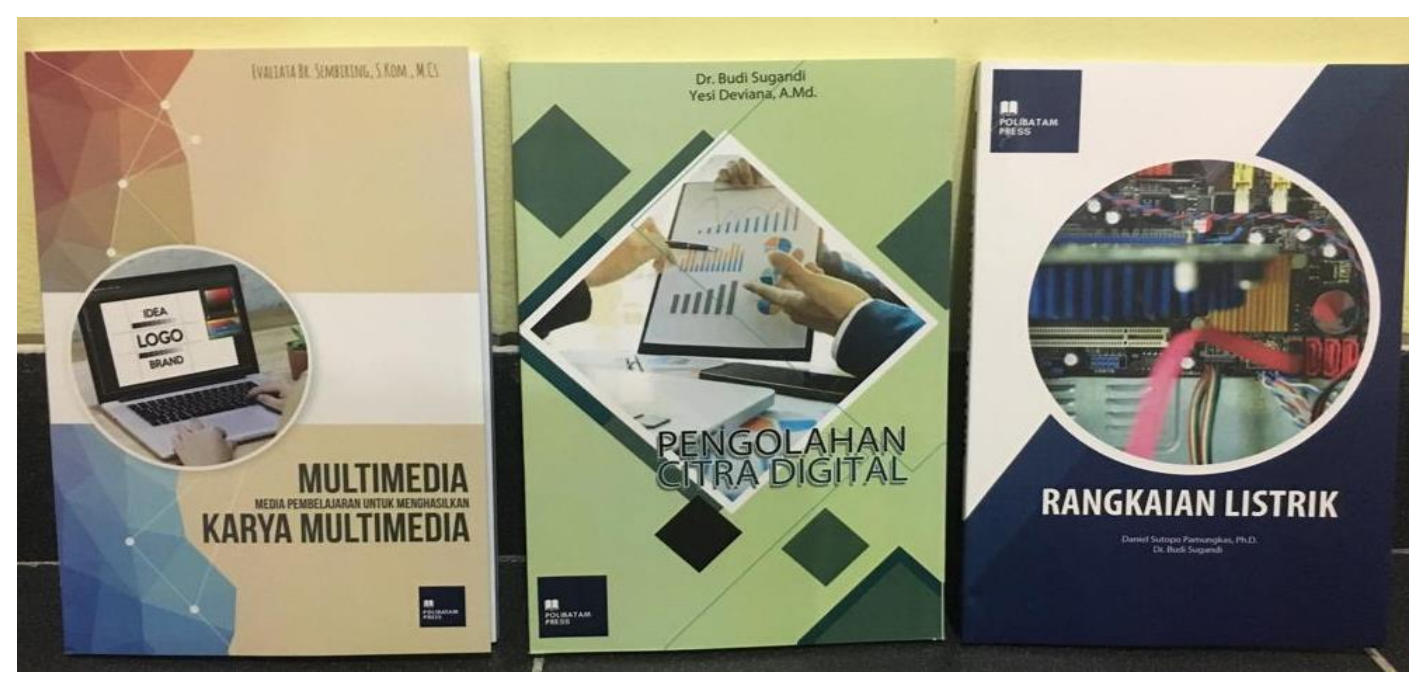

Figur 1. Produk yang telah dihasilkan Polibatam Press 
Kelebihan dari produk Polibatam Press yaitu produknya lebih murah dan telah menggunakan digital printing. Salah satu keunggulan dari digital printing dimana metode percetakan dari gambar berbasis digital (file), dapat langsung dicetak di berbagai media dengan cara yang lebih cepat. Keunikan dari produk ini yaitu memproduksi sesuai dengan pesanan dan tidak ada batasan jumlah minimal pemesanan. Selain itu, Polibatam Press telah menjadi anggota Ikatan Penerbit Indonesia (IKAPI) yang diakui oleh Kemenristek Dikti. Tanda anggota IKAPI Polibatam Press terlihat pada gambar berikut:

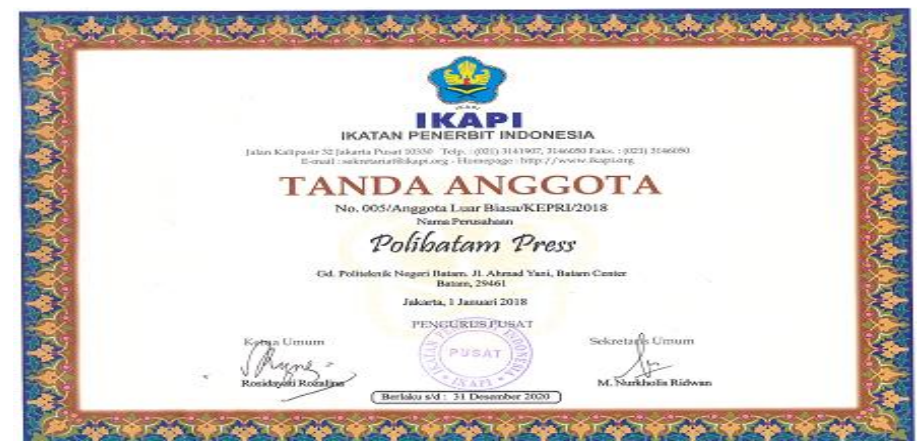

Figur 2. Tanda Anggota IKAPI Polibatam Press

Strategi yang digunakan untuk mengembangkan usaha Polibatam Press yaitu strategi penjaminan mutu produksi dan meningkatkan kepercayaan konsumen dengan cara sebagai berikut: pertama, menyusun jadwal bagi dosen dalam mensupervisi proses produksi. Kedua, menggunakan peralatan modern dengan tingkat akurasi yang tinggi. Ketiga, menggunakan software grafis, misalnya Adobe Ilustrator, dalam proses pra-produksi dan dilakukan pejaminan mutu produk melalui quality control. Proses produksi percetakan Polibatam Press untuk sebuah buku, modul, maupun brosur dibagi tiga tahapan antara lain: pra cetak (prepress), cetak (press) dan pasca cetak (post-press).
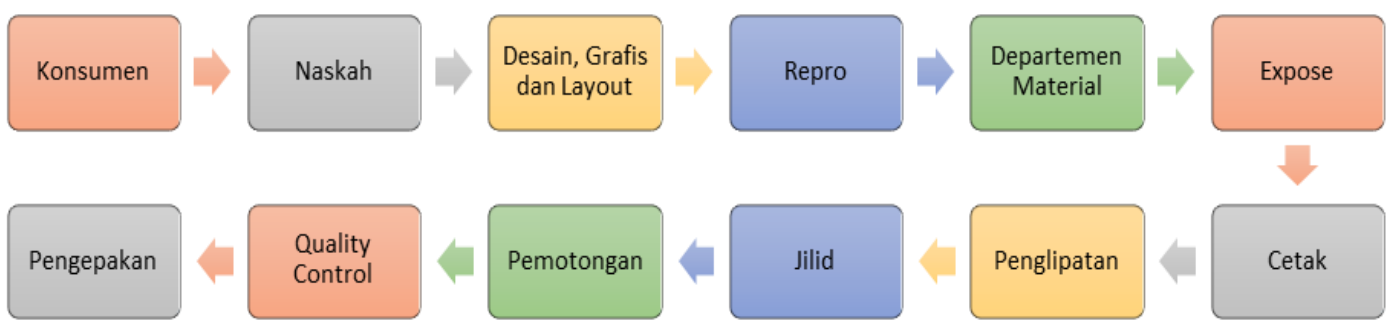

Figur 3. Proses Produksi Polibatam Press

Strategi yang digunakan akutanbilitas pekerjaan dilakukan dengan menerapakan prosedur baku yang berupa Standar Operasional Prosedur (SOP), selain itu juga menerapkan 
prosedur yang dikembangkan dari hasil-hasil penelitian dosen dan mahasiswa. Sedangkan strategi yang dilakukan untuk meningkatkan produktivitas penulis dengan melalui sayembara yang akan diberikan reward tertentu. Program tersebut diharapakan dapat meningkatkan jumlah dosen dalam menulis dan meningkatkan kualitas tulisan. Strategi dalam menjamin akuntabilitas keuangan dilakukan dengan melakukan pencatatan keuangan Polibatam Press menggunakan software dan melakukan audit sebelum laporan keuangan tersebut sebelum disampaikan ke stakeholder.

\section{PEMBAHASAN}

\section{Rekruitmen Sumber Daya Manusia}

Polibatam Press membutuhkan bantuan untuk menjalankan operasional. Polibatam Press melakukan rekruitmen dari mahasiswa aktif di Politeknik Negeri Batam (Hartatik, 2014). Tujuan dipilihnya mahasiswa antara lain: pertama, direkrutnya mahasiswa magang dari segi biaya lebih efisien dan murah dengan dibandingkan merekrut professional. Kedua, menjadi media praktikum bagi mahasiswa jurusan manajemen bisnis. Ketiga, menciptakan jiwa wirausaha bagi mahasiswa. Keempat, menjadi tempat aplikasi dan meningkatkan kompetensi mahasiswa jurusan manajemen bisnis dan teknik informatika. Terakhir, meningkatkan keberdayaan masyarakat melalui peningkatan pengetahuan dan ketrampilan. Polibatam Press merekrut sebanyak 8 (delapan) mahasiswa dari Prodi Teknik Multimedia dan Jaringan (4 orang) dan Prodi Akuntasi (4 orang).

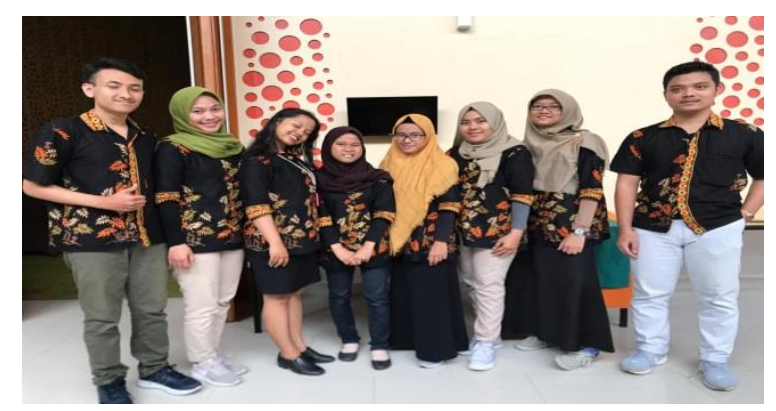

Figur 4. Mahasiswa aktif yang direkrut oleh Polibatam Press

\section{Bahan Baku}

Bahan baku yang digunakan dalam proses produksi percetakan dibagi menjadi dua yaitu intangible dan tangible. Bakan baku intangible berupa materi ajar atau manuscripts yang akan dicetak menjadi buku. Sumber bahan baku intangible berasal dari dosen pengajar 
Doi. 10.33373/jmb.v3i2.2045

Minda Baharu, Volume 3, No 2 Desember 2019

https://www.journal.unrika.ac.id/index.php/MNDBHRU

P-ISSN 2656-0631; E-ISSN 2614-5944

Hal. 107- 120

maupun tim pengajar. Polibatam Press telah melakukan sosialisasi dan koordinasi di setiap jurusan di Politeknik Negeri Batam untuk menjamin ketersediaan naskah/manuscripts. Politeknik Negeri Batam memiliki empat jurusan yaitu Jurusan Manajemen Bisnis, Teknik Informatika, Teknik Elektro dan Teknik Mesin. Dari keempat jurusan tersebut, terbagi menjadi 15 program studi dimana masing-masing program studi setiap semester membutuhkan buku ajar maupun modul praktikum.
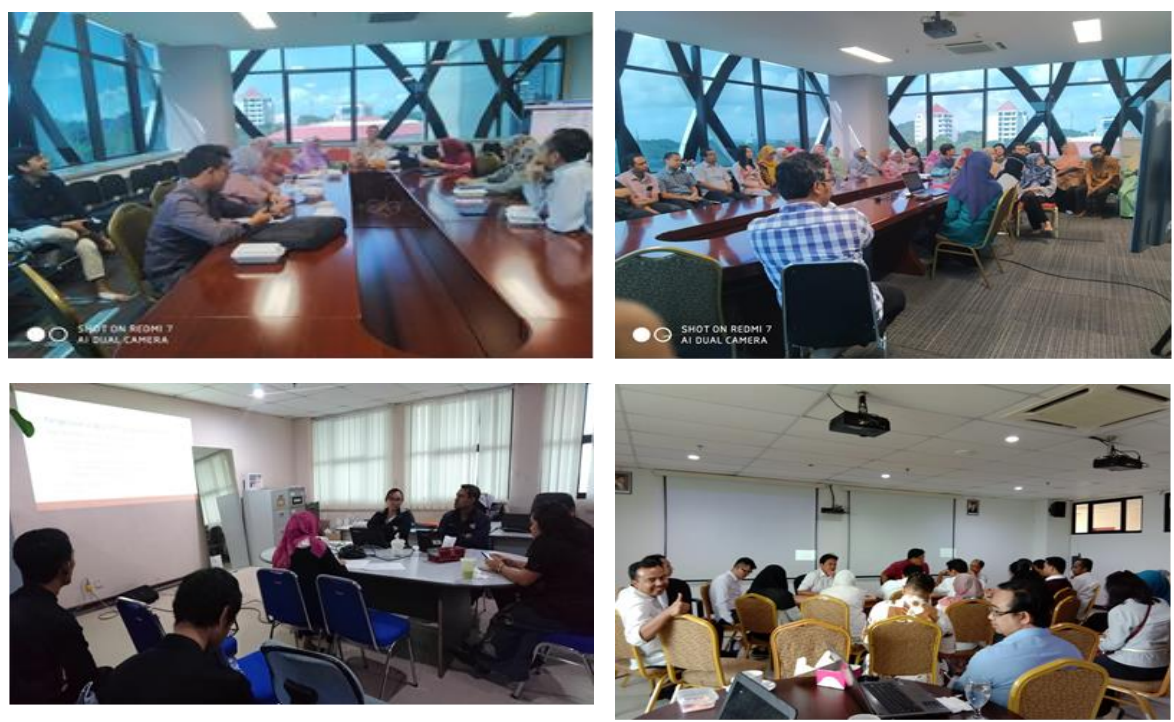

Figur 5. Koordinasi dan sosialisasi di semua jurusan

Bahan baku intangible selanjutnya berupa software yaitu Adobe Illustrators, Adobe Acrobat Reader dan Microsoft Office (diperlihatkan pada Tabel 1). Software tersebut digunakan dalam proses pra-produksi.

Tabel 1. Bahan baku intangible (Software)

\begin{tabular}{|c|c|c|c|c|}
\hline Nama software & Fungsi & \multicolumn{3}{|c|}{ Ilustrasi } \\
\hline Adobe Illustrator & $\begin{array}{l}\text { - Untuk mendesai sampul buku yang } \\
\text { terdiri dari ilustrasi gambar maupun } \\
\text { vector } \\
\text { - }\end{array}$ & $=$ & 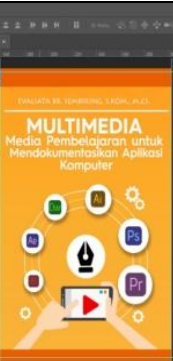 & 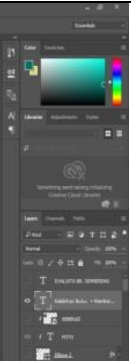 \\
\hline
\end{tabular}




\begin{tabular}{|l|l|c|}
\hline Nama software & \multicolumn{1}{|c|}{ Fungsi } & \\
\hline $\begin{array}{c}\text { Adobe Acrobat } \\
\text { Reader }\end{array}$ & $\begin{array}{l}\text { Untuk membaca, memberi notasi, mencari, } \\
\text { verifikasi, menandai secara digital dan } \\
\text { mencetak data dengan format Portable } \\
\text { Document Format atau PDF }\end{array}$ \\
\hline $\begin{array}{c}\text { Microsoft Office } \\
\text { (Word) }\end{array}$ & $\begin{array}{l}\text { Mengatur tata letak buku } \\
\text { Untuk memeriksa aksara naskah buku } \\
\text { mulai dari kata, gambar, tabel, tanda } \\
\text { baca dan lain lain yang berhubungan } \\
\text { dengan isi naskah }\end{array}$ & \\
\hline
\end{tabular}

\section{Pemasaran}

Sistem pemasaran yang telah dilakukan salah satunya dengan melalui pemasangan banner di lokasi pintu masuk gedung Politeknik Negeri (Figur 5). Pemasangan banner disesuaikan dengan aturan yang berlaku yaitu di depan tangga dan bersebelahan dengan lorong Lift/evalator. Posisi ini sangat strategis dimana setiap hari orang berlalu lalang melalui pintu tersebut. Detail pemasangan banner dapat dilihat pada Figur 5.
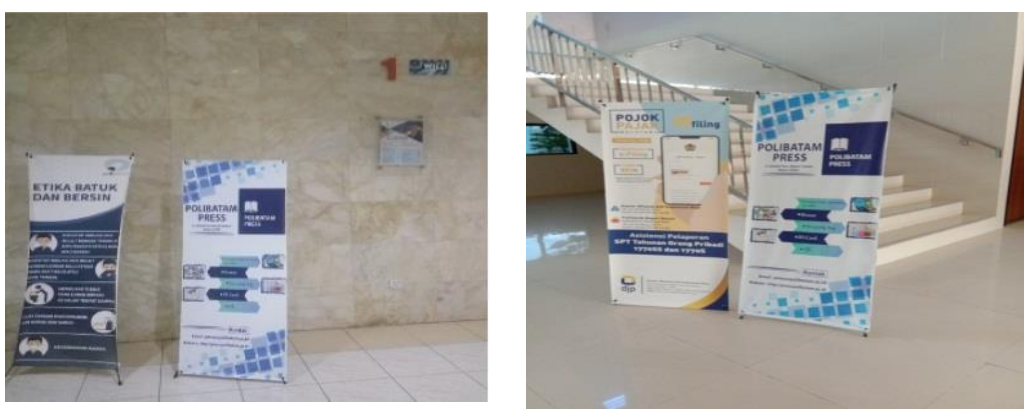

Figur 6. Pemasangan banner Polibatam Press

Media pemasaran lain yang digunakan yaitu melalui media sosial. Media sosial yang digunakan saat ini berupa: facebook (https://www.facebook.com/polibatam.press.3) dan Instagram (https://www.instagram.com/polibatampress/), telah membangun website (https://press.polibatam.ac.id/) berisi produk yang telah dihasilkan untuk memperluas pasaran, serta membangun komunikasi ke customer melalui berbagai media seperti email 
Doi. 10.33373/jmb.v3i2.2045

Minda Baharu, Volume 3, No 2 Desember 2019

https://www.journal.unrika.ac.id/index.php/MNDBHRU

(press@polibatam.ac.id) dan whatsapp. Konten pada Facebook dan Instagram berupa berbagai produk dan jasa serta testimoni dari konsumen Polibatam Press (Figur 7).

\section{Sarana dan Prasarana}

Polibatam Press mendapatkan fasilitas dari Politeknik Negeri Batam berupa ruangan yang digunakan proses produksi (Gambar 7). Ruangan ini dilengkapi dengan fasilitas listrik, air, pendingin ruangan serta Internet. Sarana yang tersedia berupa PC, laptop, printer, meja, kursi, televisi, whiteboard, lemari display, serta loker. Ruangan ini digunakan Bersama dengan unit bisnis lain yang dimiliki Politeknik Negeri Batam yaitu Galeri Investasi dan Tax Center.

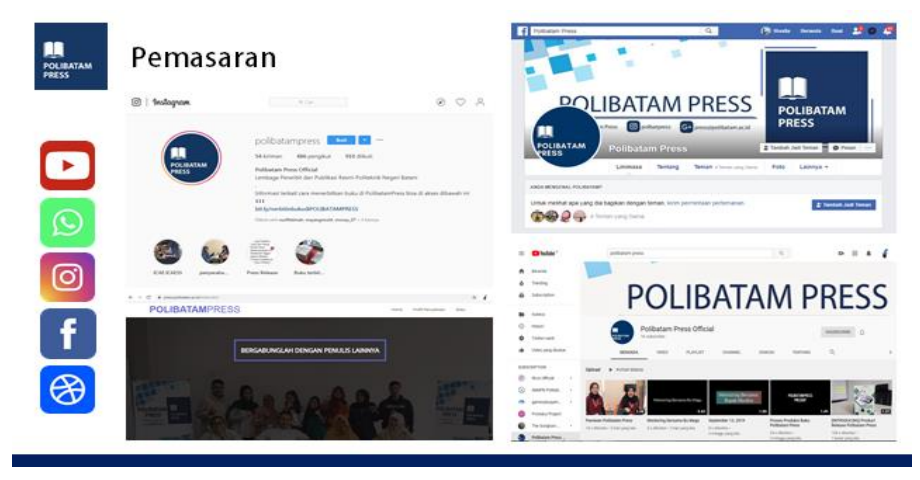

Figur 7. Media pemasaran yang digunakan Polibatam Press melalui media sosial

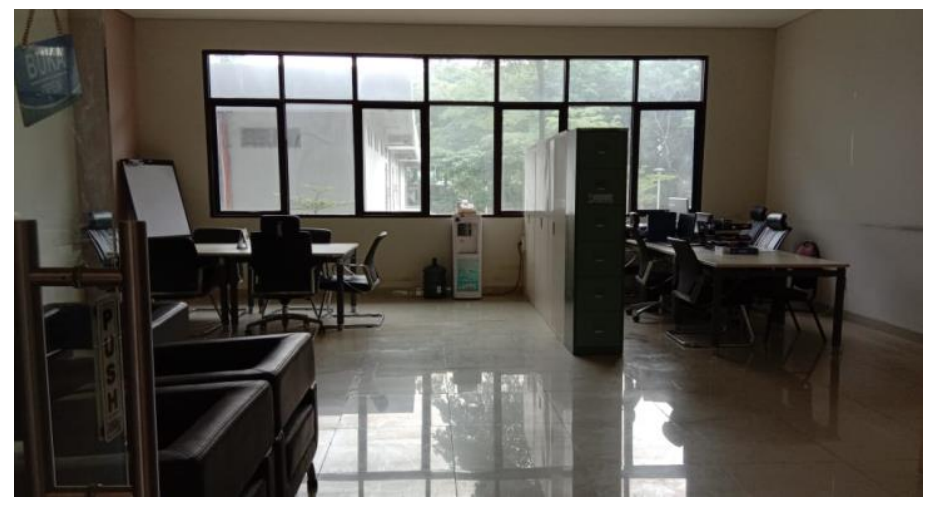

Figur 8. Ruangan Polibatam Press

\section{Standar Operasional Prosedur (SOP) Pelayanan Konsumen}

SOP pelayanan konsumen bertujuan setiap konsumen (penulis) memperoleh pelayanan yang sama dan tetap menjaga tingkat kepuasan konsumen. SOP pelayanan konsumen terdiri dari 6 (enam) tahapan, yaitu: (1) Penulis mengisi Sales Order Form, (2) Teknis Format Penulisan Naskah, (3) Pemrosesan Naskah, (4) Penerbitan ISBN, (5) Pembuatan Dummy dan Percetakan, (6) Administrasi dan Pendistribusian. 


\section{Standar Operasional Prosedur (SOP) Produksi}

Standar Operasional Prosedur Produksi diperlukan guna menjamin keberlangsungan produksi secara kotinyu dan diharapkan dapat mengurangi produk yang reject. Standar Operasional Produksi terdiri dari 5 (lima) bagian, yaitu: (1) Anatomi Buku: (Sampul buku : depan, punggung, dan belakang); (2) Bahan Awal (Preliminaries): halaman prancis, halaman undang-undang, halaman sampul, halaman katalog dalam terbitan, daftar isi, daftar gambar, daftar tabel, dan kata pengantar; (3) Bahan Isi (Text Matter): Pendahuluan, Bab dan bagian, Tabel dan Ilustrasi Gambar, Kutipan dan Penutup; (4) Bahan akhir (postliminaries): Daftar pustaka, Glosarium/daftar istilah, Lampiran, Indeks, Biografi Penulis; (5) Bentuk dan Ukuran Buku (Mulyadi, 2017; Sidarta, 2013).

\section{Standar Quality Control}

Penyusunan standar quality control ini bertujuan untuk memberikan pelayanan prima kepada konsumen dan menjaga kualitas produk. Standar quality control terdiri dari 3 (tiga) tahap yaitu: copy editing, visual editing dan proofreading (Sidarta, 2013).

\section{Proses Produksi}

Proses produksi percetakan Polibatam Press untuk sebuah buku, modul, maupun brosur dibagi tiga tahapan antara lain: pra cetak (pre-press), cetak (press) dan pasca cetak (post-press) (Mulyadi, 2017). Tahap pertama yaitu bagian administrasi menerima pesanan dari konsumen yang berupa naskah yang akan dicetak. Selanjutnya ke bagian desain. Pada tahapan ini meliputi naskah, persiapan area cetak, gambar grafis, pembuatan desain, setting warna, layout, serta penyesuaian gambar dan teks sehingga menghasilkan file cetak berkualitas tinggi. Hasil akhir dari tahapan ini berupa materi siap untuk proses cetak (Repro). Seluruh ketersediaan bahan baku yang digunakan dilakukan croscek terlebih dahulu ke bagian material dalam hal ini dirangkap oleh bagian administrasi.

Tahap kedua bagian produksi yang berupa proses cetak merupakan proses penggadaan gambar maupun teks yang ada pada acuan ke bahan yang akan dicetak dengan menggunakan mesin cetak. Terdapat empat hal yang harus diperhatikan dalam tahap ini antara lain: substrate, acuan cetak, tinta dan media penekan.

Tahap terakhir yaitu pasca cetak (post cetak) yaitu proses printing menggunakan teknik digital printing. Dengan diterapkannya digital printing tersebut tidak ada batasan 
minimal pesanan yang harus dicetak. Untuk proses printing, Polibatam Press melakukan perjanjian kerjasama dengan UMKM percetakan yang ada di Batam.

Proses selanjutnya yaitu Quality control, bagian ini melakukan seleksi antara produk yang baik dan tidak layak berdasarkan standar quality control. Terakhir yaitu pengepakan dimana produk siap untuk diserahkan kepada konsumen. Secara lengkap proses produksi diilustrasikan pada Figur 9.
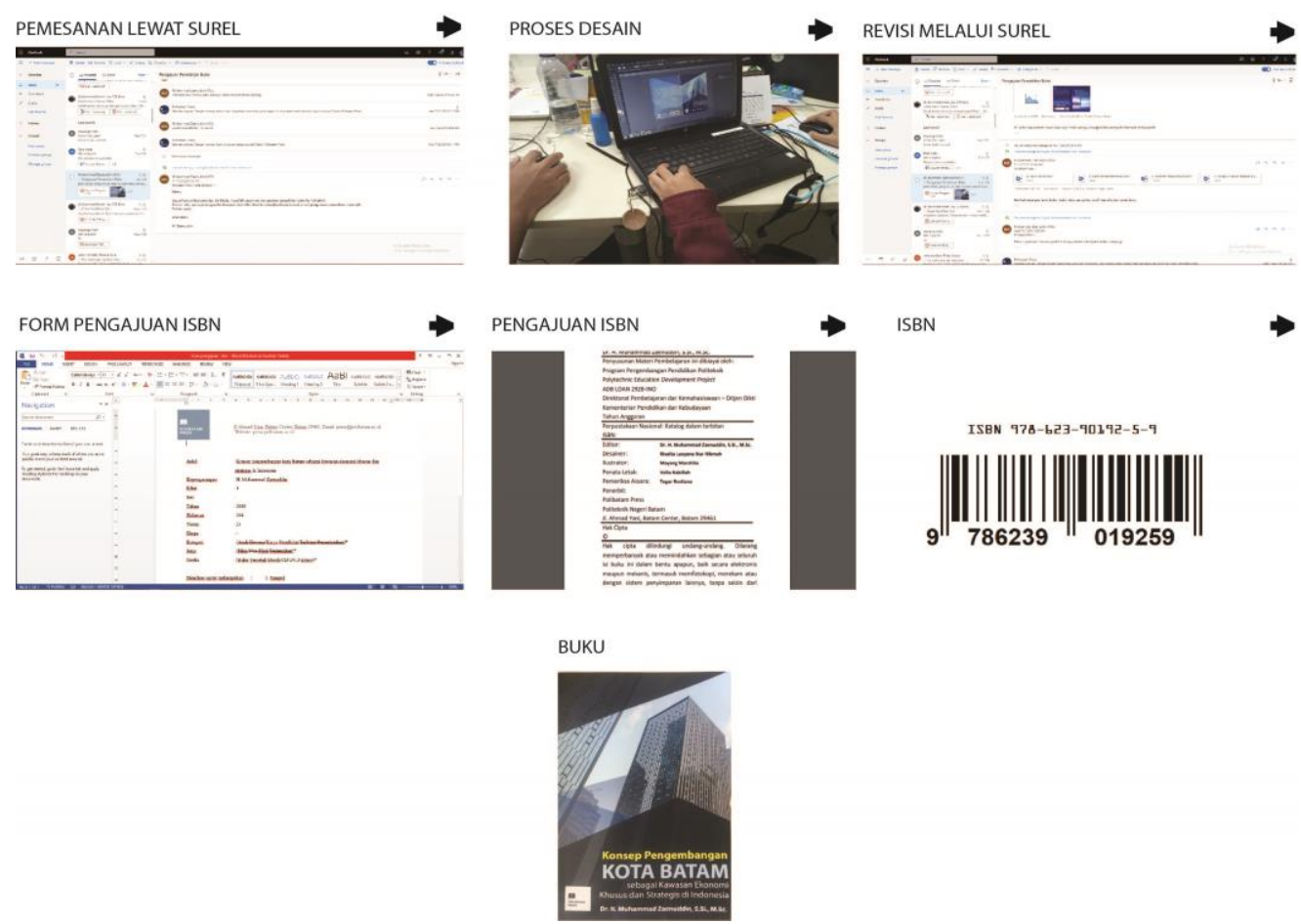

Figur 9. Proses Produksi Penerbitan Buku di Polibatam Press

\section{Produk yang Telah Dihasilkan}

Tahun 2019 Polibatam Press saat ini sudah menghasilkan sebanyak (10) sepuluh buku dan telah memiliki ISBN (Figur 10). Selain menerbitkan buku ajar, Polibatam Press juga menyediakan jasa advertising atau produk melalui diversifikasi produk guna memenuhi kebutuhan konsumen. Jasa-jasa advertising berupa desain pamflet, backdrop, sticker, name tag, sertifikat, kartu nama, poster hasil penelitian sampai mencetak hasilnya. Selain itu produk lain yang telah dihasilkan yaitu: seminar kit (notes, pena), tas, seragam kepanitiaan disajikan pada Figur 11. 


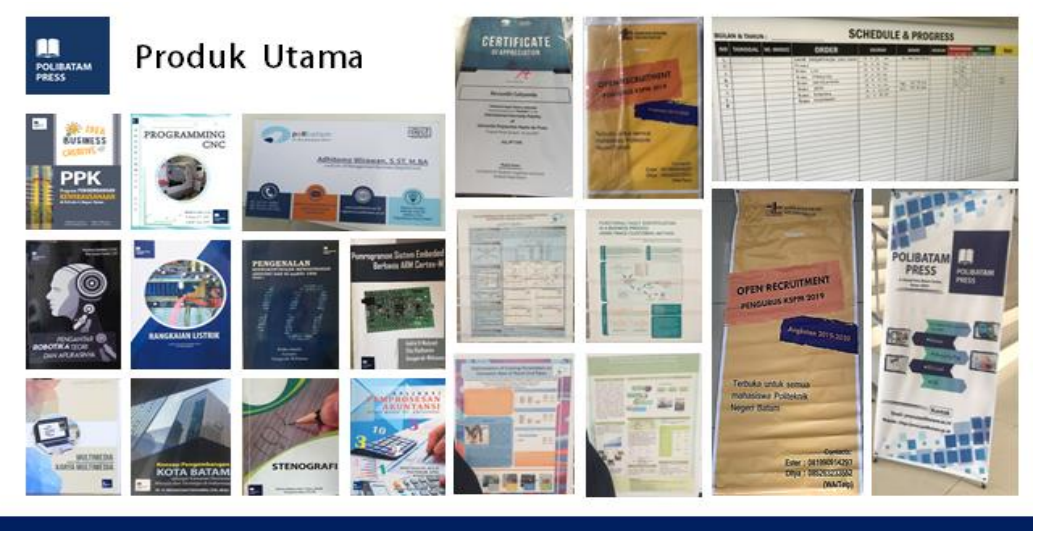

Figur 10. Produk utama Polibatam Press

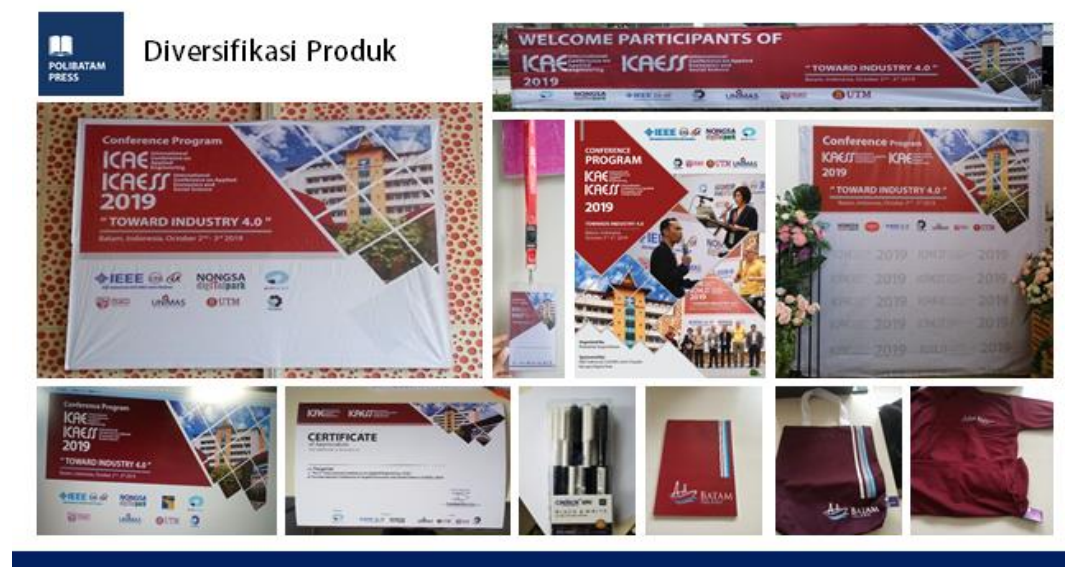

Figur 11. Diversifikasi produk Polibatam Press

\section{Manajemen}

Polibatam Press berdiri dibawah tanggung jawab Direktur Polibatam. Polibatam Press dipimpin oleh seorang Ketua. Untuk menjalankan operasional Polibatam Press dipimpin oleh Kepala Operasional dibantu oleh; (a) Bagian Account Executive sebanyak dua orang yang bertanggung jawab pada administrasi, ISBN, quality control, dan humas serta dokumen pendukung lainnya; (b) Bagian Financial Accounting sebanyak dua orang bertanggung jawab pada pencatatan penerimaan, pengeluaran kas, pembayaran pajak, gaji dan penyusunan laporan keuangan; (c) Editor sebanyak satu orang dan bertanggung jawab dalam mengedit konten buku; (d) Bagian Desain sebanyak dua orang, bertanggung terhadap desain dan layout produk yang akan dicetak; (e) Bagian produksi sebanyak satu orang yang bertanggung jawab proses cetak sampai dengan penjaminan kualitas produk (Hartatik, 2014).

\section{Finansial}


Tahun pertama Polibatam Press lebih berfokus pada penerbitan buku ajar dan modul praktikum. Kontribusi dana atau dukungan finansial dari Politeknik Negeri Batam diperuntukan untuk sewa ruangan dan listrik, internet dan telepon. Diestimasikan kontribusi yang diberikan oleh Polibatam Press sebanyak 7\% dari laba bersih setelah pajak.

Proses pengeluaran maupun pemasukan untuk seluruh biaya-biaya dilakukan menggunakan bukti transaksi serta disetujui oleh pihak yang berwenang. Bukti transaksi tersebut selanjutnya dilakukan pencatatan dengan menggunakan software agar menghasilkan laporan keuangan yang nantinya sebagai bentuk pertanggungjawaban oleh pengelola kepada stakeholders (Lestari, 2019). Proses penyusunan laporan keuangan Polibatam Press disajikan pada Figur 12. Proses pencatatan dilakukan dari bukti transaksi ke buku jurnal selanjutnya di posting ke buku besar dan buku pembantu, terakhir penyusunan Laporan keuangan yang berupa Laporan Laba Rugi, Laporan Perubahan Modal, Laporan Posisi keuangan dan Laporan Arus Kas.

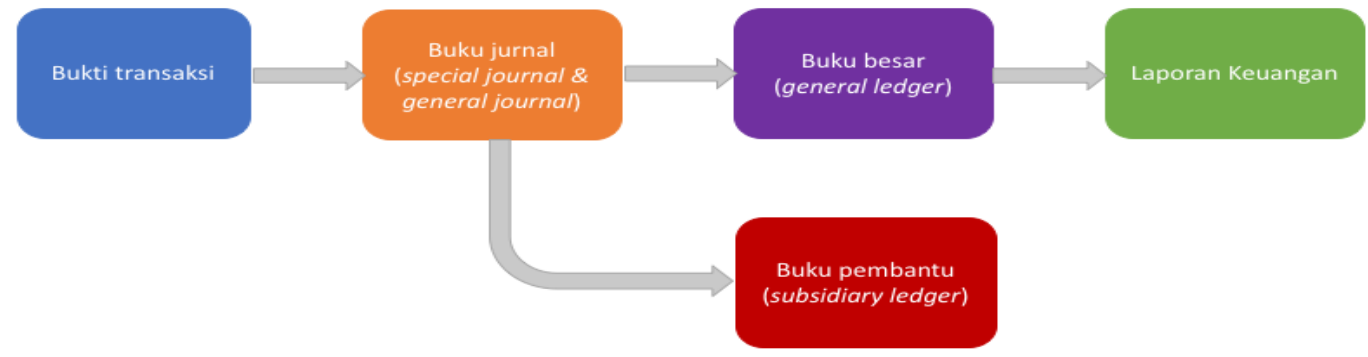

Figur 12. Diversifikasi produk Polibatam Press

Hasil penjualan produk yang telah dihasilkan oleh Polibatam Press diperlihatkan pada beberapa diagram pada Figur 13. Sedangkan laporan keuangan Polibatam Press dapat dilihat pada Figur 14.
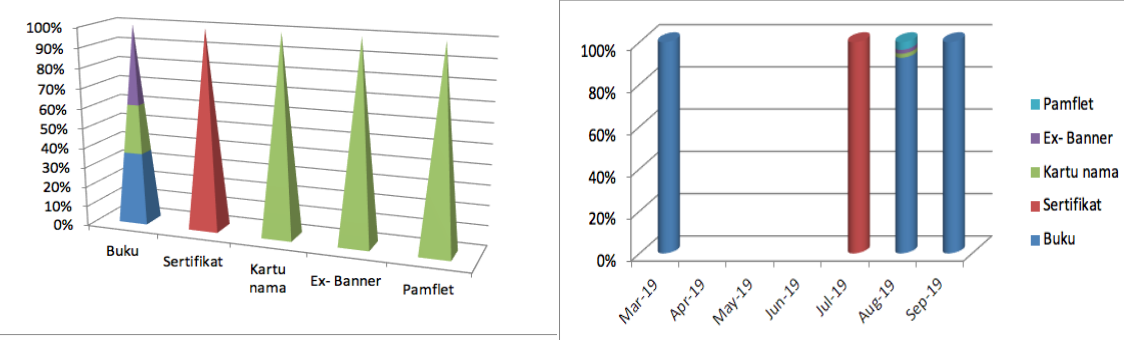


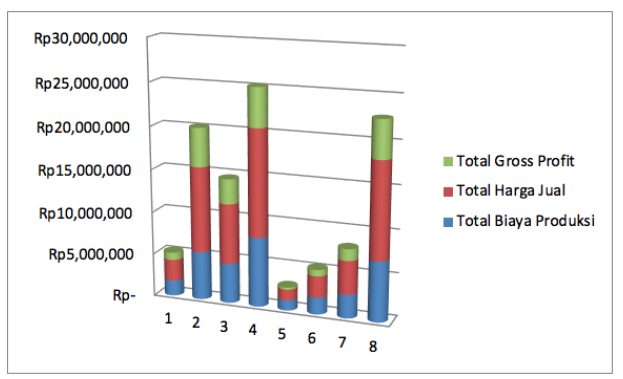

Figur 13. Penjualan produk Polibatam Press yang telah dilakukan

\begin{tabular}{|c|c|c|c|}
\hline \multicolumn{4}{|c|}{ Statement of Financial Position } \\
\hline \multicolumn{4}{|c|}{ Agustus 2019} \\
\hline \multicolumn{4}{|c|}{ In Currency (Rp) } \\
\hline & & Current 2019 & Ending \\
\hline Cash & - & 226.500 & 226.500 \\
\hline Cash In Bank & 8.476 .000 & $(4.364 .900)$ & 4.111 .100 \\
\hline Account Receivable & 87.662 .500 & 13.830 .000 & 101.492 .500 \\
\hline Office Supplies & 90.000 & 955.900 & 1.045 .900 \\
\hline Book Sample & - & 530.000 & 530.000 \\
\hline Total Assets & & & 107.406 .000 \\
\hline Account Payable & - & 7.392 .000 & 7.392 .000 \\
\hline Unearned Revenue & 81.272 .500 & $(6.400 .000)$ & 74.872 .500 \\
\hline Total Liabilities & & & 82.264 .500 \\
\hline Current Year Earning & 14.956 .000 & 10.185 .500 & 25.141 .500 \\
\hline Total Equity & & & 25.141 .500 \\
\hline Total Liabilities \& Equity & & & 107.406 .000 \\
\hline
\end{tabular}

Figur 14. Laporan Keuangan Polibatam Press

\section{KESIMPULAN}

Politeknik Negeri Batam membentuk Polibatam Press sebagai sarana civitas akademika untuk mengatualisasikan diri baik dalam karya buku ajar atau modul praktikum. Untuk menjalankan operasional Polibatam Press tersebut, telah dilakukan berbagai macam kegiatan, yaitu: (1) rekruitmen sumber daya manusia, yang terdiri dari mahasiswa aktif dari Prodi Multimedia dan Jaringan dan Prodi Akuntansi; (2) melakukan sosialisasi ke seluruh jurusan dan program studi di Politeknik Negeri Batam; (3) menyusun Standar Operasional Prosedur (SOP) untuk pelayanan konsumen, produksi dan quality control; (4) melakukan pemasaran melalui banner dan media sosial; (5) menjalankan manajemen sesuai struktur organisasi yang telah direncanakan. Dari berbagai kegiatan yang telah dilakukan tersebut, maka telah dihasilkan sebanyak 10 (sepuluh) buku ber-ISBN dan berbagai produk lain seperti kartu nama, spanduk, seminar kit, dan sebagainya. Dari sisi finansial, dapat dilihat pada Laporan Keuangan Polibatam Press bahwa telah terjadi peningkatan pendapatan dari tahun sebelumnya. Selanjutnya, ketersediaan buku ajar dan modul praktikum dalam rangka mendukung tridarma perguruan tinggi civitas akademika Politeknik Negeri Batam. 


\section{UCAPAN TERIMA KASIH}

Penulis mengucapkan terima kasih kepada Ditjen Penguatan Riset dan Pengembangan Kementrian Riset, Teknologi, dan Pendidikan Tinggi yang telah memberi dukungan finansial terhadap Program Pengabdian Masyarakat melalui skema PPUPIK Tahun 2019 - 2021 serta Politeknik Negeri Batam.

\section{DAFTAR PUSTAKA}

Deepublisher. (2019). Deepublisher. Retrieved Agustus 20, 2019, from Deepublisher: https://penerbitdeepublish.com/pentingnya-isbn/

Hartatik, I. P. (2014). Buku Praktis Mengembangkan SDM. Yogyakarta: Laksana.

IKAPI. (2019). Retrieved Agustus 20, 2019, from https://www.ikapi.org/sejarah-ikapi/

IKAPI.(2019). IKAPI. Retrieved Agustus 20, 2019, from IKAPI: https://www.ikapi.org/anggota-ikapi/

Kurikulum Berbasis Kompetensi dan SKKNI Program Studi Akuntansi Politeknik Negeri Batam tahun 2016.

Lestari, Nanik. (2019). Aplikasi pemrograman akuntansi. Polibatam Press.

Mulyadi. (2017). Sistem Akuntansi. Jakarta: Salemba Empat.

PDDIKTI. (2018). Statistik Pendidikan Tinggi 2018. Statistik Pendidikan Tinggi 2018, pp. 21-22.

Polibatam. (2018, September). Statistik Pegawai Polibatam per Semptember 2018. Statistik Pegawai Polibatam per Semptember 2018, pp. 1-2.

Sidarta, Kurniawan, (2013), Studi Deskriptif Pengelolalaam usaha percetakan pada perusahaan Keluarga CV. Satrio Agung Surabaya (Rencana Pengembangan Fungsi Produksi dan Operasional. Jurnal AGORA. Vol.1, No.1 Hal 1 - 10.

Wikipedia. (2019). Wikipedia. Retrieved Agustus 20, 2019, from Wikipedia: https://id.wikipedia.org/wiki/Penerbit 